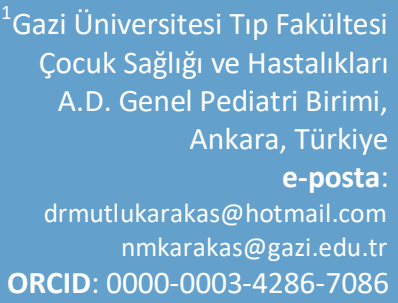

Atıf İçin: Nazmi Mutlu

KARAKAŞ, Preoperatif Değerlendirme: Pediatrist Bakış Açısı Pediatristin Preoperatif

Değerlendirmesi, Balıkesir Medical Journal, 2020;4(2):1-12

Başvuru Tarihi: 09.03.2020

Kabul Tarihi: 08.06.2020 Yayınlanma Tarihi: 23.06.2020

Sorumlu Yazar: Nazmi Mutlu KARAKAŞ, Gazi Üniversitesi Tıp Fakültesi Çocuk Sağlığı ve Hastalıkları A.D. Genel Pediatri Birimi, Ankara, Türkiye e-posta: drmutlukarakas@hotmail.com nmkarakas@gazi.edu.tr

\title{
Preoperatif Değerlendirme: Pediatrist Bakış Açısı
}

\section{Pediatristin Preoperatif Değerlendirmesi}

\author{
Preoperative Evaluation: Perspective of Pediatrician \\ Preoperative Evaluation of Pediatrician
}

Nazmi Mutlu KARAKAŞ ${ }^{1}$

Öz

Amaç: Preoperatif dönemde çocuk hasta değerlendirmenin tetkik ve tedavi ile psikolojik olmak üzere iki önemli yönü vardır. Anestezi hekimleri gibi pediatristler de preoperatif değerlendirme katılımının olması bu sürecin iki yönüyle de daha az sorunla atlatılmasına katkı sağlamaktadır. Hastanemizde çeşitli sebeplerden dolayı anestezi alması gereken hastaların pediatri poliklinik değerlendirmesi analitik olarak sunmak amaçlanmıştır.

Gereç ve Yöntemler: Aralık 2018 ile Mart 2019 tarihleri arasında 3 aylık dönemde anestezi öncesi değerlendirme için ayaktan polikliniğe başvuran tüm hastalar çalışmaya alındı. Hazırlanan formlara eş zamanlı hasta değerlendirmeleri kaydedildi ve incelendi. Başvuran hiçbir hasta çalışma dışı bırakıımadı.

Bulgular: 152 çocuk anestezi öncesinde değerlendirildi. Çocukların ortalama yaşları ay cinsinden $64,05 \pm 52,27$ idi. Hastaların $89(\% 58,6)^{\prime}$ u erkek, $63(\% 41,4)$ tanesi kızdı. \%44,7 ile en sık göz hastalıkları tarafından yönlendirilen çocuklara preoperatif değerlendirme yapılmıştır. Hastaların \%17,1' inde anestezi ertelenmesi önerilmiş. En sık neden ise üst solunum yolu enfeksiyonu olduğu görülmüştür. 20 çocukta yan dal konsültasyonu ihtiyacı görüldü. En sık \%40 oranında Çocuk Kardiyoloji yan dal konsültasyonu olduğu saptandı. Ortalama erteleme süresi 5,5 gün idi. 23 çocukta ise mevcut tanılarına ek saptanan sorunlar nedeniyle araştırıldı.

Sonuç: Pediyatristler hasta çocuk ve ailesini cerrahi ve anesteziye hazırlama sırasında ve sonrasında perioperatif bakım ekibinin önemli bir parçası olmak konumundadırlar. Hem tıbbi durumunun ideal koşullara getirilmesi hem de aile ve çocuğun kaygısının azaltııması noktasında önemli sorumluluk taşırlar. Ayrıca altta yatan diğer hastalıkları için dikkatli olmalıdırlar.

Anahtar Kelimeler: preoperatif; değerlendirme; pediatrist

\section{ABSTRACT}

Aim: Pediatric patients in the preoperative period have two important aspects: psychological assessment with examination and treatment. The participation of pediatricians such as anesthesiologists in the preoperative evaluation contributes to the reduction of these problems in both aspects. The aim of this study is to present the pediatric polyclinic evaluation analytically for the patients who need to receive anesthesia for a variety of reasons within a 3-month period.

Materials and Methods: All patients who applied to the outpatient clinic for pre-anesthesia evaluation in the 3-month period between December 2018 and March 2019 were included in the study. While evaluating the patients, concurrent patient evaluations were recorded in the prepared forms. No patient was excluded from the study.

Results: 152 children were evaluated before anesthesia. The mean age of the children was $64.05 \pm 52.27$ months. 89 $(58,6 \%)$ of the patients were male and $63(41,4 \%)$ were female. $44,7 \%$ of them were referred from the Ophthalmology department in $17,1 \%$ of patients, anesthesia was postponed. The most common cause was upper respiratory tract infection. 20 children showed the need for subspecialty consultation. It was found that $40 \%$ of the cases had Pediatric Cardiology subspecialty consultation. The mean postponement time was 5,5 days. 23 children were investigated because of additional health problem.

Conclusion: Pediatricians are in a position to be an important part of the perioperative care team during and after surgery and anesthesia. They have important responsibility both for bringing the medical status to ideal conditions and for reducing the anxiety of the family and the child. They should also be aware of other underlying diseases.

Keywords: preoperative; evaluation; pediatrician 


\section{Giriş}

Pediyatristler hastaları ve ailelerini anestezi ve cerrahi için hazırlamaya yardım etmede kilit rol oynayan doktorlardır. Çocuklar küçük yetişkinler değildir, yetişkin hastalar için geçerli standart uygulamalar kullanılmamalıdır. Hem ailelerin hem de hastaların preoperatif dönemde iyi hazırlanması, başarılı perioperatif sonuçlara neden olur. Çocukların duygusal ihtiyaçlarına ve ailelerin çocuklarının bakımı konusundaki endişelerine özel dikkat göstermek, pediyatristler için preoperatif değerlendirmenin temel taşıdır. Anestezi uzmanlarının preoperatif değerlendirmesine benzer şekilde pediyatristler de anestezi uygulanacak bir çocuğun değerlendirmesine iki açıdan yaklaşmalıdır. Birinci yaklaşım çocuğun tıbbi durumu ve gerekli ise uygun şekilde tedavi edilmesini kapsarken, diğer yaklaşım çocuğun psikolojik durumunu ve ailelerin duygusal yönlerini de değerlendirerek aradaki dengeyi sağlamaktır (1).

Preoperatif hazırlıktaki ilk adımlar, çocuğun temel sağlık koşullarına göre, mümkün olan en iyi sağlık durumunda olup olmadığını belirlemek ve eşzamanlı akut olarak araya giren hastalıkları yönetmektir. Anahtar kavram, hastanın tıbbi durumunun, ameliyathaneye sunarken "optimize edilmesi" gerektiğidir. Hasta hazırlamadaki ikinci adım, aileyi ameliyathaneye gitme süreci hakkında eğitmek ve kendileri ve çocukları için en iyi olan süreç için yardımcı olmaktır (2). Çocukları ameliyata hazırlamak için "standart" bir prosedür yoktur ve mevcut kaynaklar bir kurumdan diğerine büyük farklılıklar gösterebilir.

Bu çalışmada, radyolojik görüntüleme, muayene ve ameliyat gibi sebeplerle anestezi alması planlanan çocukların anestezi öncesi değerlendirmelerinin analitik olarak incelenmesi amaçlanmıştır.

\section{GEREÇ VE YÖNTEMLER}

Aralık 2018 ile Mart 2019 tarihleri arasında 3 aylık dönemde anestezi öncesi değerlendirme için ayaktan polikliniğe başvuran tüm hastalar çalışmaya alındı. Yatan hasta pediatrik anestezi öncesi değerlendirmeleri çalışma dışı bırakıldı. Hastalar poliklinikte pediatri doktoru tarafından değerlendirilip konsültasyon kâğıdı doldurulurken eş zamanlı olarak planlanan çalışma formu da dolduruldu. Formda yer alan bilgiler Tablo 1' de verilmiştir. Ayaktan başvurmuş olup herhangi bir nedenle çalışma dışı bırakılan hasta olmadı. Anestezinin herhangi bir nedenler ertelenmesi halinde, hastanın doldurulan form numarası kaydedildi. Tekrar değerlendirme sırasında erteleme süresi ve erteleme nedeni kaydedildi. Değerlendirilen çocukların laboratuvar verileri hastane bilgi yönetim sisteminden alındı. Veriler, SPSS 20.0 programı ile analiz edildi ve Kategorik veriler sayı (n) ve yüzde (\%) ile ifade edildi.

Bu çalışmada, Helsinki protokolü komitesinin gereklerine uygun olarak yapıldı ve Gazi Üniversitesi Etik kurulu tarafından onaylandı (Araştırma Kod No: 2019-007). 


\begin{tabular}{|c|c|}
\hline Ad Soyad & Kanama diyatezi hikâyesi \\
\hline Protokol No & Ailede Anestezik problem ya da özel hastalık \\
\hline Yaş & Konjenital Anomali var mı? Varsa Nedir? \\
\hline Cinsiyet & Fizik Muayene (patolojik olanlar, anatomik dahil) \\
\hline Boy & Laboratuvar (Özellikli Olanlar) \\
\hline Kilo & $\mathrm{Hb}$ \\
\hline Vücut kitle indeksi & Mcv \\
\hline Preop tanısı & AntiHbs: \\
\hline Planlanan Operasyon & Onkolojik Hikaye: \\
\hline İlgili Cerrahi Klinik & Gelişme Geriliği var mı? \\
\hline Olgu tipi & Büyüme geriliği var mı? \\
\hline Öykü & Doğum ağırlığı/zamanı: \\
\hline Kullandığı ilaç & Yandal Konsultasyonu gerekli mi? Kime? \\
\hline Geçirdiği Hastalıkları & Pediatri Harici Konsultasyonu gerekli mi? Kime? \\
\hline Op geçirdi ise postop dönemde bulantı-kusma oldu mu? & Aşıları tam mı? \\
\hline Allerji hikayesi & \\
\hline
\end{tabular}

Tablo 1. Form bilgileri

\section{BULGULAR}

Çalışmamız sırasında pediatri polikliniğine yönlendirilen 152 çocuk anestezi öncesi

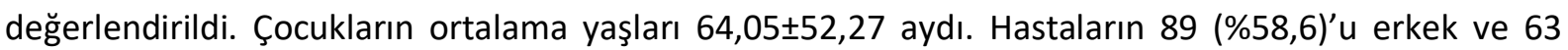
$(\% 41,4)^{\prime} u$ kızdı.

Çocukların anestezi öncesi hangi klinikten yönlendirildikleri Tablo 2'de gösterilmiştir. Hastaların yaklaşık yarısına yakını göz hastalıkları tarafından yönlendirilmiş olup ikinci sıklıkla değerlendirilen yaklaşık her beş hastanın birini ortopedi ve travmatoloji polikliniğinden yönlendirildiği görüldü.

\begin{tabular}{|l|c|c|}
\hline \multicolumn{1}{|c|}{ Klinik } & $\boldsymbol{n}$ & Yüzde \% \\
\hline Göz Hastalıkları & 68 & 44,7 \\
\hline Ortopedi ve Travmatoloji & 30 & 19,7 \\
\hline Kulak Burun Boğaz & 14 & 9,3 \\
\hline Diş Hekimliği & 8 & 5,3 \\
\hline Beyin ve Sinir Cerrahi & 8 & 5,3 \\
\hline Üroloji & 5 & 3,3 \\
\hline Çocuk Cerrahi & 5 & 3,3 \\
\hline Plastik ve Rekons Cerrahi & 5 & 3,3 \\
\hline Çocuk Nöroloji & 4 & 2,7 \\
\hline Çocuk Onkoloji & 3 & 1,9 \\
\hline Çocuk Göğüs & 1 & 0,6 \\
\hline Çocuk Gastroenteroloji & 1 & 0,6 \\
\hline
\end{tabular}

Tablo 2. Hastaların gönderildikleri kliniklerin dağılımı 
Çocukların hangi nedenle anestezi almaları gerektiği ve ameliyat oldukları, operasyon tanıları ve dağılımları Tablo 3'de gösterildi. Göz Hastalıkları tarafından anestezi eşliğinde muayene veya ameliyat yapılaması planlanmış olan glokom hastaları birinci sırada yer alırken, ameliyat nedenleri içerisinde en sık neden Ortopedi ve Travmatoloji tarafından yapılması planlanan kemik deformitesianomalisi düzeltme ameliyatıydı. 28 çocuk muayene sırasında anestezi alması gerektiği için değerlendirildi. Bu çocuklardan 20'sinin $(\% 71,4)$ göz muayenesi için anestezi alması gerekirken, 8'inin $(\% 28,6)$ diş çekimi ve muayenesi için anestezi alması gerektiği öğrenildi. Radyolojik görüntüleme işlemlerinden ise en sık manyetik rezonans görüntüleme $(\% 72,8)$ öncesi değerlendirme istendiği bulundu.

\begin{tabular}{|l|l|c|c|}
\hline & & $\boldsymbol{n}$ & Yüzde \\
\hline En Sık Tanılar & Glokom & 16 & 10,7 \\
\hline & Kemik deformitesi-anomalisi & 14 & 9,3 \\
\hline & Kemik kırı̆̆ı & 13 & 8,6 \\
\hline & Retina dekolmanı & 10 & 6,6 \\
\hline & Katarakt & 9 & 5,9 \\
\hline & Strabismus & 9 & 5,9 \\
\hline & Diş çekimi/diş çürü̆̆̈̈/diş dolgusu & 6 & 3,9 \\
\hline & Gelişimsel Kalça Displazisi & 5 & 3,2 \\
\hline & Adenoid Vegetasyon & 5 & 3,2 \\
\hline & Diğer Nedenler & 65 & 42,7 \\
\hline & Ameliyat & 102 & 67,2 \\
\hline & Muayene & 28 & 18,4 \\
\hline & Radyoloji & 22 & 14,4 \\
\hline & Manyetik Rezonans Görüntüleme & 16 & 72,7 \\
\hline & Bilgisayarlı Tomografi & 6 & 27,3 \\
\hline
\end{tabular}

Tablo 3. En sık tanılar, yapılan işlemler ve radyolojik dağılım

Çocukların \%23,6'sının sürekli ilaç kullanım hikâyesi mevcuttu. En sık kullanılan ilaçlar göz damlası, antiepileptik ilaçlar, tiroid ilaçları ve antihipertansiflerdi. \%22,3 çocukta kronik hastalık hikâyesi mevcuttu. En çok karşılaşılan tanılar kronik böbrek yetmezliği, hipotroidi, ureteropelvik darlık ve epilepsiydi.

\begin{tabular}{|l|c|c|c|}
\hline & & $\boldsymbol{n}$ & Yüzde \\
\hline Geçirilmiş Anestezi Öyküsü & var & 88 & 57,8 \\
\hline Anestezi alma sayısı & yok & 64 & 42,2 \\
\hline & 1 & 63 & 71,7 \\
\hline & 2 & 11 & 12,5 \\
\hline & 3 & 7 & 7,9 \\
\hline & 4 ve fazla & 7 & 7,9 \\
\hline
\end{tabular}

Tablo 4. Geçirilmiş anestezi öyküsü ve anestezi alma sayısı 
Çocukların \%57,8' inde daha önceden geçirilmiş anestezi öyküsü vardı. Bir ya da birden fazla ameliyat geçiren çocukların sayısal oranları Tablo 4'de verilmiştir. En az bir kez anestezi alan çocuk sayısı $63(\% 71,7)$ idi. Sadece $5(\% 3,3)$ çocukta alerji hikayesi mevcuttu. Ailesinde kanama diyatezi hikayesi olan ya da daha önceden anestezi ile ilgili problemle karşılaşılmış hiçbir hasta yoktu. \%36,1 çocuğun konjenital anomalisi vardı.

Çocukların \%9,2 fizik muayenede patolojik bulgu tespit edildi. Bunlar sıklıkla üst solunum yolları hastalıkları bulguları ve kardiyak üfürümleriydi. Hemoglobin değeri ortalaması $12,35 \pm 1,4 \mathrm{~g} / \mathrm{dl}$ 'idi. Serolojik değerler tüm çocukların hepatit B'ye karşı korumalı olduğunu gösteriyordu ve tüm çocuklarda HIV ve HCV pozitifliği yoktu. Çocukluk çağı aşılarını yaptırmamış sadece bir çocuk vardı. Hastaların $18(\% 11,8)$ de gelişme geriliği, \%23,6'sında büyüme geriliği tespit edildi. Çocukların \%84,2'si term bebek, \%15,8'i preterm bebeklerdi. Ortalama doğum ağırlığı 3092,53 \pm 759,04 gramdı.

\%13,1 çocuğa preoperatif değerlendirme için pediatri yan dal konsültasyonu istendi. Sıklıkla hangi yan dallardan konsültasyon istendiği Tablo 5'de gösterildi. Pediyatri yan dal harici konsültasyon istenmesi gereği olmadı. \%17,1 çocuğun ameliyatı bizim isteğimizle ertelendi. Erteleme nedenleri $\% 53,9$ 'u üst solunum yolları enfeksiyonuna bağlı, \%46,1'nin ise yan dal konsültasyon sonucu beklendiği için gelişti. Çalışmamızda çocukların \%57,8' inde daha önce anestezi alma ve ameliyat olma öyküsü olduğu öğrenildi. Tamamında postoperatif bulantı-kusma (POBK) olmadığı görüldü.

\begin{tabular}{|l|l|c|c|}
\hline & & $n$ & yüzde \\
\hline Pediatri yan dal konsültasyonu istendi mi? & Evet & 20 & 13,1 \\
\hline & Hayır & 132 & 86,9 \\
\hline Konsultasyon istenen yan dal bölümleri & Çocuk Kardiyoloji & 9 & 45 \\
\hline & Çocuk Nefroloji & 5 & 25 \\
\hline & Çocuk Göğüs & 2 & 10 \\
\hline & Çocuk Endokrin & 1 & 5 \\
\hline & Çocuk Nöroloji & 1 & 5 \\
\hline & Çocuk Allerji & 1 & 5 \\
\hline & Çocuk Metabolizma & 1 & 5 \\
\hline Pediatri Harici Konsültasyon istendi mi? & Hayır & 0 & 0 \\
\hline & Evet & 152 & 100 \\
\hline Operasyon erteledi mi? & Evet & 26 & 17,1 \\
\hline & Hayır & 126 & 82,9 \\
\hline & Konsültasyon sonucu beklendi & 12 & 46,1 \\
\hline & ÜSYE & 14 & 53,9 \\
\hline
\end{tabular}

Tablo 5. Konsültasyon istenen bölümlerin ve ertelenme nedenlerinin dağılımı

Anestezi öncesi değerlendirmede, 23 (\%15,1) çocuğun mevcut tanılarının çocuk sağlığı ve hastalıkları yönünden değerlendirilmediği ve buna neden olacak nedenler yönünden araştırılmadığı görüldü. Özellikle ilgili anabillim dalına dioğrudan sevk ile gelen glokom, katarakt, strabismus, kemik 
deformiteleri ile anomalisi olan çocukların, bu duruma neden olabilecek hastalıklar yönünden çoğunun değerlendirilmemiş olduğu görüldü. Bu çocukların anestezi öncesi muayenelerine ek olarak, mevcut durumlarına neden olabilecek hastalıklar içinde değerlendirildi. Değerlendirme sonucunda etyoloji araştırımlası için ilgili ana dal ve/veya yan dal bölümlerine konsültasyonları yapıldı

\section{TARTIŞMA}

İdeal olarak, preoperatif değerlendirmeler, hastanın ameliyat durumunu ve son dakika iptallerini önlemek için ameliyat gününden önce yapılır. Özellikle erişkinlerin küçültülmüş hali olmayan çocuk hastalarda preoperatif değerlendirmenin bir basamağının pediyatrist tarafından yapılması en uygun şartlarda cerrahi ve anestezi geçirilmesi için önemlidir (1). Hastanemizde başta cerrahi operasyonlar olmak üzere anestezi alması planlanan tüm 18 yaş altı çocuklar pediatri polikliniğinde değerlendirilmekte ve gerekirse yan dal birimleri tarafından da muayene edilip konsültasyon notları tamamlanmaktadır. İhtiyacı olan hastalara postoperatif dönemde de bakım hizmeti verilmektedir. Aralık 2018 ile Mart 2019 ayları arasında cerrahi, radyolojik görüntüleme ya da anestezi eşliğinde muayene öncesi pediyatri konsültasyonlarını değerlendirdiğimiz hastaların 102 $(\% 67,2)$ tanesi tıbbi sebebine yönelik ameliyat olacakken, $28(\% 18,4)$ tanesi muayene için $22(\% 14,4)$ tanesi de sadece radyolojik işlem sırasında hareketsiz kalabilmek için anestezi alması gerekiyordu. Çocukların büyük bir kısmı glokom, retina dekolmanı, strabismus ve katarakt gibi göz muayenelerine hazırlanan gruptu. Göz muayenelerini veya ameliyatlarını takip eden en sık cerrahi girişim ise kemik kırıklarını kapsayan ortopedik girişimlerdi. Anestezi öncesi değerlendirme 23 (\%15,1) çocukta, anesteziye engel durum saptanmasa da büyüme-gelişme geriliği, glokom, katarakt, strabismus, kemik deformiteleri ile anomalisi vardı. Bu çocuklar, saptanan ek sorunları ve anestezi almasına neden olan hastalığa neden olabilecek organik hastalıkları nedeniyle değerlendirilmiş olup altta yatan tanı için ilgili yan dal ya da başka ana dal bilim dallarına yönlendirildi. Hastalarımızı, sadece anestezi öncesi değerlendirme yanında, çocuk sağlığı ve hastalıkları yönünden değerlendirilmesi önemli olup, aileler uygun şekilde yönlendirilmesi önemlidir. \%36,1 hastada konjenital anomali olduğu tespit edildi. Bunlar genellikle operasyon sürecini etkilemeyecek düzeyde anomalilerdi. Anomalilerin özellikleri ile ilgili perioperatif dönemde dikkat edilmesi gereken noktalar var ise konsültasyon notu ile cerrahi ve anestezi ekibi bilgilendirildi.

Anestezi planlamasında hastanın öyküsü ve tıbbi geçmişi önemlidir. Çocuğun nörolojik gelişimi ve fonksiyonları, havayolu anomali varlığı, kardiak ve pulmoner fonksiyon sorgulaması (efor kapasitesi, uyku apnesi gibi), kanama-pıhtılaşma geçmişi, endokrin ve renal hastalıkları ile kronik ilaç maruziyeti ya da kullanımı dikkatle sorgulanmalıdır (2). \%22,3 hastada kronik hastalık öyküsü 
belirledik. Beş hastada böbrek yetmezliği, beş çocukta hipotroidi, beş hastada epilepsi hikayesi olduğunu ve üç hastada ureteropelvik darlık nedeni ile takip edildiğini tespit ettik. Kronik böbrek yetersizliği olan hastalar hemodiyalize girdikleri ve Çocuk Nefroloji tarafından düzenli izlemleri yapıldığı öğrenildi. Hareket hastalığı, erişkinlerde postoperatif bulantı ve kusma için risk faktörü iken, çocuklarda da ön haberci olabilir. Daha önceki cerrahi girişimlerindeki (POBK) hikayesi mutlaka not edilmelidir (2). Çalışmamızda çocukların \%57,8' inde daha önce anestezi alma ve ameliyat olma öyküsü olduğu öğrenildi. Tamamında POBK olmadığı görüldü. Daha önce böyle bir deneyimin yaşanmamış olması yeni yapılacak olan girişim sonrasında da bulantı- kusma oranlarını arttırması beklenmemektedir. Ailelere bu durum hakkında bilgilendirme yapıldı. Çalışmamıza dahil edilen tüm çocuklarla taşıt tutması ya da hareket hastalığı gibi yakınmaların olmadığı öğrenildi.

Perioperatif dönemde hastanın sürekli kullandığı ilaçların kesilmesi, dozunun ayarlanması veya devam edilmesi ile ilgili bilgi aileye pediyatrist tarafından mutlaka verilmelidir. Preoperatif açlık süreleri göz önüne alınarak gerekirse damar yolu planlaması yapılmalı ve aileye bu durum hakkında yeterli önerilerde bulunulmalıdır. Reçetesiz kullanılan ilaçlar, vitaminler ve bitkisel kaynaklı destekler potansiyel kanama ve ilaç etkileşimleri açısından özellikle sorgulanmalıdır. Özel spesifik bir neden yoksa (aspirin- kardiyak durum ilişkisi gibi) bu tür ilaçlara devam edilmemelidir $(3,4)$. Ankete katılan ebeveynlerden alınan bilgiye dayanarak \%23,6 çocuk hastanın sürekli ilaç tedavisi altında olduğunu belirledik. En sık kullanılan ilaç gruplarının ise antiepileptik, tiroid hastalıkları için kullanılan ilaçlar, göz damlaları ve antihipertansifler olduğunu tespit ettik. Pediatrist özellikle epilepsi tanılı hastaların en son nöbet geçirdiği zamanı not etmeli özellikle valproik asit gibi kanama riskini arttırabilen ilaçlar açısından anestezi ve cerrahi ekibini bilgilendirici not koymalıdır. Cerrahi gerekliliğe göre gerekirse Çocuk Nöroloji değerlendirmesi istenerek antiepileptik değişimi talep edilebilir. Bizim sadece 5 hastamızda epilepsi hikayesi vardı. Değerlendirmelerimiz sırasında stabil olan hastalara direk onay verirken tedavisinde stabil olmayan ve kanama riskinden dolayı valproik asit tedavisi alan 2 çocuk için pediyatrik nöroloji konsültasyonu istendi. Bu hastaların hiçbirinde postoperatif dönemde sıkıntı yaşanarak rekonsultasyon istenmedi. Ancak cerrahi öncesi enfektif endokardit profilaksisi alması gereken $9(\% 5,9)$ hasta için bilgi notu konuldu. Sadece beş hasta anti-hipertansif ilaç kullanmakta ve tansiyon ölçümlerinde düzenli olduğu görüldü. Anestezi öncesi döneme kadar kullanmaları önerildi. Kronik böbrek yetmezliği olan 5 hastamız çocuk nefroloji bölümünün önerileri ile stabil bir şekilde cerrahiye sunuldu.

Aile hikâyesi anamnez sırasında bazı durumlarda özellikle önem kazanır: Malign hipertermi, süksinilkolin sonrası uzamış paralizi ( psödokolin esteraz eksikliği), kanama diyatezi ve POBK hikayesi. $\mathrm{Bu}$ durumlarla perioperatif dönemde karşılaşılmasının katastrofik sonuçları olabilir. Kanama hikayesinin var olması da hastanın pediyatrik hematoloji tarafından ayrıntılı incelenmesi gerekliliğine 
de yol açabilir. Ankette ilave araştırmaya sebep olabilecek herhangi bir aile hikayesi ile karşılaşılmadı. Sadece \%3,3 hastanın ailesinin alerjiye eğilimli olduğu ama bu nedenle tedavi almadıkları ve hafif düzeyde olduğu görüldü. Malign hipertermide genetik ön planda olup tanınması güç durumdur, özellikle myopatik hasta grubunda dikkat edilmelidir. Musküler distrofiler pek çok sistemi etkilediklerinden dolayı anestezi sırasında özellikle dikkatli olmak gereklidir (5). Sadece bir hastanın konjenital anomalisi olması ve muskuler distrofi şüphesi olması nedeniyle malign hipertermi dikkat edilmesi yönünde anestezi öncesi dosya notuna eklendi.

Sağ|ıklı olan ve minimal riskli cerrahi geçirecek olan çocuklarda rutin laboratuvar testlerine gerek yoktur. Intraoperatif dönemde kanama beklentisi olan hastalarda sadece hemoglobin bakılması yeterlidir (1). Spesifik hastalığı olan çocuklarda daha ileri inceleme (yan dal konsültasyonu) ve testler gerekebilir. Çalışmada ortalama Hemoglobin düzeyi 12,3-mg/dl olarak bulundu. Yandaş hastalığı olan hastaların özellikli test değerlendirme sonuçları normal sınırlar içinde değerlendirildi. Yirmibeş çocukta aynı gün içerisine tekrar kan alma gerekliliği doğmuştur. Çocuklarda kan almanın zorlukları bilinmektedir. Kan sonuçlarını etkileyen en önemli faktörlerde biri de hemolizdir. Maalesef ki potasyum, böbrek ve karaciğer fonksiyonları gibi önemli kan sonuçlarının normal olduğu görmek pediatri hekimi için anestezi öncesi önemlidir. Hemolize ikincil olduğu düşünülse de bu değerlerin normal sınırlarda olması gerekmektedir.

\%13,1 hasta ileri değerlendirme açısından genel poliklinik haricinde spesifik yan dal bölümlerininde önerileri alınmak üzere ilgili birimlere yönlendirildi. En sık (\%45) çocuk kardiyoloji birinci sırada yer alırken \%25 le ikinci sırada çocuk nefroloji takip etti. Daha az sıklıkta ise göğüs, endokrin, allerji ve nöroloji yandal bölümlerinin önerileri alındı. Anestezi öncesi etkileyecek durumlar için pediatri yan dalları harici herhangi branştan konsültasyon talep edilmedi. Pediatri dışı yan dal istekleri çocuklarda saptanan ana problemle ilişkili tanıya yönelik konsültasyonlardı.

Çocuk Kardiyoloji değerlendirmelerinin en sık olmasının ana nedenlerinden birisi de üfürüm duyulmasıdır. Preoperatif değerlendirme de II/VI' ya kadar ve masum üfürüm karakterinde olan üfürümlerin danışılmasına gerek yoktur. Ama maalesef ki çoğu başvuran çocuk, sağlam çocuk izlemlerini yaptırmamış olup, daha önce üfürüm varlığı sorgulandığından bilmediklerini ve olmadığını söylediği için kafa karışıklıkları ortaya çıkmaktadır. Özellikle bir yaş altı çocukları olmak üzere çoğu yeni ortaya çıkmış üfürüm olduğu düşünülerek yan dal konsültasyonu istendi. Sonuç olarak da yan dal değerlendirmesi beklendiği için ameliyatın ertelenmesi gerekliliği ortaya çıkmıştır. Sağlam çocuk izlemi yapan tüm hekimlerin ailelere masum üfürüm hakkında bilgilendirmesi ve farkındalığının olması, bu tür ertelemelerin ve iş kaybının önüne geçebilir. Özellikle kılavuzlarda sol kalp hipertrofisi, uzun QT sendromu ve ritim bozukluğu düşünülen hastaların çocuk kardiyolojisi değerlendirmesi önerisi bilinmektedir. Daha önceden prostetik kapak takılan ve bu nedenle antikoagulan alan hastalar 
da kardiyolog ve hematolojist tarafından kontrol edilmelidir. "Pacemaker" varlığı, elektrokardiografi ve ekokardiografi bulguları not edilmelidir $(6,7)$. Çalışma grubundaki 3 çocukta elektrokardiyogramında uzun QT şüphesi ve 2 çocukta sol ventrikül hipertrofisi bulgusu olması nedeniyle konsültasyon istenmiştir.

Astım, kistik fibrozis, kronik alt solunum yolu enfeksiyonu olan hastaların optimum şartlarda olması gerekir. Steroid kullanım öyküsü, uyku apnesi bulunması ve geçirilmiş toraks cerrahisi not edilmelidir. Sistemik veya alt solunum yolu enfeksiyonu olmaksızın akut üst solunum yolu enfeksiyonu olan çocukların cerrahisi genellikle ertelenmez ama ateş, wheezing veya produktif öksürüğü olan hastaların elektif cerrahileri ertelenmelidir (8,9). Cerrahinin ertelenme süresi hastadan hastaya değişmekle birlikte 2 hafta olarak düşünülmektedir. Değerlendirme süreci içerisinde yaptığımız muayenelerde \%17,1 hastada operasyonun tarafımız değerlendirmesi sonucu ertelenmesi talep edildi. Erteleme istemenin nedenlerinin $\% 53,9$ da üst solunum yolları enfeksiyonu tespit edildi. Tedavi planlaması yapılarak sonucunda yeniden konsültasyon yapıldı. Ertelemenin $\% 46,1$ ini ise yan dal konsültasyonuna yönlendirdiğimiz hastaların sonuçlarını beklemek oluşturdu. Ortalama bekleme süresi 5,5 gün idi. Üst solunum yolu enfeksiyonları için minimal 7 gün bekleme önerildi ve hasta tekrar değerlendirmeye çağırıldı. Fakat yan dal konsültasyon sonucunun süresi değiş̧kenlik gösterdiği için aileye, ilgili cerraha ve anestezi ekibine net bir bekleme süresi verilemedi.

Zamanında doğan infantlarla kıyaslandığında 37. haftadan önce doğan preterm infantlarda genel anestezi sonrası postoperatif apne ve bradikardi görülme sıklığı daha fazladır. Dikkat edilmesi gerek bir durum olarak tıbbi özgeçmişinde bronkopulmoner displazi öyküsü olmasıdır (10). Çalışma kapsamına giren \%15,8 hasta preterm doğum hikâyesine sahipti. Bu çocuklarda herhangi bir fizik muayene ya da laboratuvar sorununa rastlanmadı. Ancak bu hastaların yoğun bakım geçmişleri sorunsuz gözükse de preterm doğum hikayesi özelliği olan hastalar konsültasyon kağıdında özellikle belirtildi.

Hava yoluna, mediastene ve önemli vasküler yapılara yakın kitlelere özellikle anestezi indüksiyonu sırasında dikkat etmek gerekir (11). Hastaların daha önceden kullandıkları Bleomisin ve Doksorubisin gibi kemoterapötik ilaçların kardiyomiyopati ve pulmoner fibrozis yan etkileri değerlendirilmelidir (12-13). Radyoterapiye bağı dokuların etkilenmesi ile ağız açıklığı, boyun haraketleri etkilenebilir (14). Hematolojik ve metabolik değişiklikler olabilir. Bu nedenle tedavi süreci ayrıntılı bir şekilde sorgulanmalıdır. Çalışmamızda 5 hastada $(\% 3,3)$ onkolojik hastalık öyküsü vardı. Ancak anestezi ve cerrahiyi tehdit edecek herhangi bir durum tespit edilmedi.

Çalışmamızda \%11,8 hastada gelişme geriliği, \%23,6 hastada büyüme geriliği vardı. Bu nedenle takip altındalardı. Ancak otizmi olan hasta ile karşılaşılmadı. Büyüme ve gelişme geriliği olan 
hastalar perioperatif dönemde bulunulan yabancı bir ortamda kognitif sıkıntılara neden olabilir. Aynı zamanda postoperatif ağrıyı tanımlamak zor olabilir bu nedenle aileye çocuğun spesifik ağrıya karşı yanıtları sorgulanmalıdır. Aileye yeterli bilgi verilmelidir. Bizde bu konuya özellikle dikkat çekerek hastaların sorun yaşamasına engel olmaya çalıştık.

Anksiyete perioperatif dönemde çocuk hasta ve ailesinde yaygın olarak karşılaşılan bir durumdur. Çocuk hastanın yaşadığı olumsuz deneyimler postoperatif dönemde kâbuslar ve agresyon gibi negatif davranış değişikliklerine neden olabilir (1). Biz çalışmamızda maalesef hasta ve yakınlarının anksiyetelerini değerlendirme imkânı bulamadık. Bu nedenle postoperatif dönemde çocukları perioperatif dönemin nasıl etkilediği konusunu araştırmaya eklemedik. Ancak 4 yaş altı çocukların, daha önce olumsuz deneyim yaşayan çocukların ve preoperatif dönemde hazırlık aşaması kısa süren çocukların anksiyetelerinin daha fazla olduğunu istatistiksel sonuca yansıtamasak ta gözlemledik.

\section{SONUÇ}

Pediyatristler hasta çocuk ve ailesini cerrahi ve anesteziye hazırlama sırasında ve sonrasında perioperatif bakım ekibinin önemli bir parçası olmak konumundadırlar. Hem tıbbi durumunun ideal koşullara getirilmesi hem de aile ve çocuğun kaygısının azaltılması noktasında önemli sorumluluk taşırlar. Ayrıca çocuk hekimleri bu çocukları sadece anestezi almaları gerektiren tanılarıyla değil, bütüncül olarak değerlendirmeleri gerekmektedir.

Çıkar Çatışması: Çıkar çatışması bulunmamaktadır.

Finansal Destek: Hiçbir kurum ya da kuruluştan finansal destek alınmamıştır.

Çalışma daha önce başka bir dergide yayınlanmamıştır ya da poster-sözlü sunum olarak sunulmamıştır.

\section{KAYNAKLAR}

1. Goldschneider KR, Cravero JP, Anderson C, Bannister C, Hardy, Honkanen A et al. The pediatrician's role in the evaluation and preparation of pediatric patients undergoing anesthesia. Pediatrics 2014; 134: 634-641.

2. Gan TJ, Meyer TA, Apfel CC, Chung F, Davis PJ, Habib AS et al. Society for ambulatory anesthesia. society for ambulatory anesthesia guidelines for the management of postoperative nausea and vomiting. Anesth Analg 2007; 105: 1615-1628.

3. Cordier W, Steenkamp V. Herbal remedies affecting coagulation: a review. Pharm Biol 2012; 50: 443-452. 
4. Beckert BW, Concannon MJ, Henry SL, Smith DS, Puckett CL. The effect of herbal medicines on platelet function: an in vivo experiment and review of the literature. Plast Reconstr Surg 2007; 120: 2044-2050.

5. Birnkrant DJ, Panitch HB, Benditt JO, Boitano L, Carter ER, Cwik VA et al. American College of Chest Physicians consensus statement on the respiratory and related management of patients with Duchenne muscular dystrophy undergoing anesthesia or sedation. Chest 2007; 132: 1977-1986.

6. Wernovsky G, Rome JJ, Tabbutt S, Rychik J, Cohen MS, Paridon SM et al. Guidelines for the outpatient management of complex congenital heart disease. Congenit Heart Dis 2006; 1 : $10-26$.

7. Wilson W, Taubert KA, Gewitz M, Lockhart PB, Baddour LM, Levison M et al; Prevention of infective endocarditis: American Heart Association Rheumatic Fever, Endocarditis, and Kawasaki Disease Committee; American Heart Association Council on Cardiovascular Disease in the Young; American Heart Association Council on Clinical Cardiology; American Heart Association Council on Cardiovascular Surgery and Anesthesia; Quality of Care and Outcomes Research Interdisciplinary Working Group. Prevention of infective endocarditis: guidelines from the American Heart Association: a guideline from the American Heart Association Rheumatic Fever, Endocarditis, and Kawasaki Disease Committee, Council on Cardiovascular Disease in the Young, and the Council on Clinical Cardiology, Council on Cardiovascular Surgery and Anesthesia, and the Quality of Care and Outcomes Research Interdisciplinary Working Group. Circulation 2007; 116: 1736-1754.

8. Elwood T, Bailey K. The pediatric patient and upper respiratory infections. Best Pract Res Clin Anaesthesiol 2005; 19: 35-46.

9. Parnis SJ, Barker DS, Van Der Walt JH. Clinical predictors of anaesthetic complications in children with respiratory tract infections Paediatr Anaesth 2001; 11: 29-40.

10. Coté CJ, Zaslavsky A, Downes JJ, Kurth CD, Wellborn LG, Warner LO et al. Postoperative apnea in former preterm infants after inguinal herniorrhaphy. A combined analysis. Anesthesiology 1995; 82: 809-822.

11. Anghelescu DL, Burgoyne LL, Liu T, Li CS, Pui CH, Hudson MM et al. Clinical and diagnostic imaging findings predict anesthetic complications in children presenting with malignant mediastinal masses. Paediatr Anaesth 2007; 17: 1090-1098.

12. Huettemann E, Junker T, Chatzinikolaou KP, Petrat, Sakka SG, Vogt L et al. The influence of anthracycline therapy on cardiac function during anesthesia. Anesth Analg 2004; 98: 941947. 
13. Hudson MM, Rai SN, Nunez C, Merchant TE, Marina NM, Zalamea $N$ et al. Noninvasive evaluation of late anthracycline cardiac toxicity in childhood cancer survivors. J Clin Oncol 2007; 25: 3635-3643.

14. Latham GJ, Greenberg RS. Anesthetic considerations for the pediatric oncology patient - part 2: systems-based approach to anesthesia. Paediatr Anaesth 2010; 20: 396-420. 